\title{
BIIB021, an Hsp90 inhibitor: A promising therapeutic strategy for blood malignancies (Review)
}

\author{
WEI HE and HUIXIAN HU \\ Department of Hematology, Jinhua Municipal Central Hospital, Jinhua, Zhejiang 321000, P.R. China
}

Received August 25, 2017; Accepted April 17, 2018

DOI: $10.3892 /$ or.2018.6422

\begin{abstract}
Heat shock proteins (HSPs) are molecular chaperones that are consistently increased to help cells survive under conditions of stress. As a member of the Hsps, Hsp90 is involved in protein post-translational maturation and disposition. This protein is ubiquitously expressed in normal cells. However, in cancer cells and particularly in hematological malignancies, Hsp90 is unexpectedly abundant to maintain levels of proteins vital for cancer pathology. Hsp90 inhibitors can target the ATP domain of Hsp90 and prohibit its exchange of ADP for ATP, leading to the degradation of client proteins and disruption of signaling cascades. Concomitantly, Hsp90 inhibitors induce tumor cell apoptosis, promote cell cycle arrest and abrogate microenvironment-derived cytoprotection. Geldanamycin,
\end{abstract}

Correspondence to: Dr Huixian Hu, Department of Hematology, Jinhua Municipal Central Hospital, 365 Renmin Road, Jinhua, Zhejiang 321000, P.R. China

E-mail: 2432380747@qq.com

Abbreviations: HSPs, heat shock proteins; CML, chronic myeloid leukemia; CLL, chronic lymphocytic leukemia; GA, geldanamycin; 17-AAG, 17-allylamino-17-desmethoxy-geldanamycin; RD, radicicol; TKIs, tyrosine kinase inhibitors; HL, Hodgkin's lymphoma; KSHV, Kaposi sarcoma-associated herpes virus; PEL, primary effusion lymphoma; LMP1, latent membrane protein 1; EBV, Epstein-Barr virus; T-ALL, T-cell acute lymphoblastic leukemia; TPL, triptolide; MDS, myelodysplastic syndrome; GISTs, gastrointestinal stromal tumors; PR, partial response; MTD, maximum tolerated dose; DLT, dose-limiting toxicity; LANA, latency-associated nuclear antigen; KS, Kaposi sarcoma; HNSCC, head and neck squamous cell carcinoma; WDTC, well-differentiated thyroid carcinoma; AML, acute myeloid leukemia; DLBCL, diffuse large B-cell lymphoma; TYK2, tyrosine kinase 2; MCL, mantle cell lymphoma; MPNs, myeloproliferative neoplasms; ATL, adult T-cell leukemia-lymphoma; MM, multiple myeloma; BMSCs, bone marrow stromal cells; CSCs, cancer stem cells; Ara-C, cytarabine; $\mathrm{CR}$, complete response; CRi, incomplete blood count recovery; DIC, disseminated intravascular coagulation; ARDS, acute respiratory distress syndrome; SD, stable disease; PTCL, peripheral T-cell lymphoma

Key words: cancer, heat shock protein 90, BIIB021, blood malignancies, clinical trial a benzoquinone antineoplastic antibiotic isolated from the bacterium Streptomyces hygroscopicus, and its derivative, 17-AAG, were first developed as Hsp90 inhibitors and exhibited effective anticancer potency. Whereas, severe side effects and low solubility restricted their application at the clinical level, BIIB021, a novel and fully synthetic inhibitor of Hsp90, is water soluble and well-tolerated. Beyond degrading oncogenic protein, BIIB021 can overcome multidrug resistance and potentiate the effects of other therapeutics. phase I/II trials have been conducted to evaluate the dosing schedules and activity of this agent. The present review focuses on the antitumor profile of BIIB021. Furthermore, given the promising efficacy of BIIB021 in leukemia and lymphoma, this review also discusses current research concerning the treatment of hematologic malignancies by targeting Hsp90.

\section{Contents}

1. Introduction

2. Effects of BIIB021 in hematologic malignancies

3. Effects of BIIB021 in solid tumors

4. Targeting Hsp90 in hematologic malignancies

5. Conclusion

\section{Introduction}

Heat shock proteins (HSPs) can be found in all cells and are key elements in the process of protein synthesis. When cells are exposed to stressors, protein misfolding, aggregation or denaturation may occur resulting in cell death. Under such difficult conditions, the expression of HSPs are increased and facilitate cell survival $(1,2)$.

Hsp90 is a member of the HSPs and is important in protein post-translational maturation and disposition. Its N-terminal domain contains a characteristic Bergerat fold (unique structural ATP-binding domain). Binding and hydrolysis of ATP induces conformational changes to Hsp90, and this allows for the binding of Hsp90 to its client proteins to help them fold their active conformation. Hsp90 inhibitor targets the ATP domain and disrupts the exchange of ADP for ATP of Hsp90 protein, thereby causing client proteins to undergo misfolding, ubiquitination and subsequent degradation by the proteasome pathway. 
Hsp90 is evolutionarily conserved and ubiquitously expressed in normal cells, accounting for as much as 1-2\% of total cellular protein (3). Cancer cells, particularly hematological malignant cells, express 2- to 10-fold higher levels of Hsp90 than normal cells. Many of its client proteins are signal transducers that are essential for tumor cell proliferation, survival and generation (3). In fact, Hsp90 is important in the acquisition and maintenance of the malignant phenotype for its unique function in transformation maintanence and growth facilitation. Moreover, cancer cells are exposed to numerous harsh conditions and rely on the function of Hsp90 to survive. As a consequence, it is rational to apply Hsp90 inhibitors in the treatment of malignancies $(4,5)$. Hsp90 inhibitors can target estrogen and progesterone receptors in breast cancer $(6,7)$, ERBB2 in ERBB2-driven xenograft models $(8,9)$, androgen receptor in hormone-sensitive metastatic prostate cancer $(10,11)$, BRAF in melanoma and colon cancer (12-15), EGFR in non-small cell lung cancer (16), Bcr-Abl in chronic myeloid leukemia (CML) (17), ZAP-70 in chronic lymphocytic leukemia (CLL) (18) and c-KIT in gastrointestinal stromal tumors (19).

Over the past few years, numerous efforts have been made to discover Hsp90 inhibitors from derivatives of natural products to fully synthetic small molecules. Geldanamycin (GA), first isolated from Streptomyces hygroscopicus as an antibiotic in 1970, can bind specifically to the ATP pocket of Hsp90 by positioning the benzoquinone ring to the entrance of the binding pocket and the ansa ring towards the bottom of the pocket (20). Once appropriately positioned, GA forms hydrogen bonds with the pocket and restrains Hsp90 in its ADP-bound conformation. This leads to immaturation and degradation of the client proteins by the proteasomal pathway $(21,22)$. GA has exhibited effective anticancer potency in pre-clinical studies. Yet, it has never been evaluated at the clinical level as it displays severe hepatotoxicity (stemming from the benzoquinone moiety), metabolical and chemical unstability and very low solubility in aqueous solution (23).

17-Allylamino-17-desmethoxy-geldanamycin (17-AAG) inhibited Her 2 in breast cancer cells with $\mathrm{IC}_{50}=31 \mathrm{nM}$ and is the first GA derivative that has proceeded to clinical trials (24). Disappointingly, the toxic profile of 17-AAG restricts its application (25). Moreover, this agent has limited solubility in water and shows reduced activity in some multidrug-resistant cells.

Radicicol (RD) is a macrocyclic lactone antibiotic originally isolated from the fungus Monosporium bonorden in 1953 (26). The co-crystal structure of RD with yeast Hsp90 shows that RD can exhibit a C-shaped conformation similar to ADP and then competitively bind to the N-terminal ATP pocket of Hsp90 (21). Thus, it restrains Hsp90 in its ADP-bound conformation and leads to degradation of client proteins, similar to GA. It has antitumor effects in vitro, but no in vivo efficacy has been noted due to its instability in serum (27). A series of RD analogs have been synthesized and evaluated at preclinical and clinical levels.

PU3 [9-butyl-8(3,4,5-trimethoxy-benzyl)-9H-purin-6ylamine], the first reported synthetic purine-scaffold inhibitor, was designed by Chiosis and colleagues (28) (Fig. 1). In a manner similar to GA, PU3 can induce protein degradation. Yet, PU3 is not as potent as 17-AAG.

Based on the structure of PU3, the aryl substituent was shifted from 8 - to the 9-position along with the NH2 from the
6- to the 2-position. Since the 9-benzyl series had poor aqueous solubility, the phenyl ring was replaced with a 2 -pyridyl group (29). BIIB021, the 3',5'-dimethyl-4'-methoxy-2'-pyridyl derivative, is soluble in biological fluids (Fig. 1). The binding affinity of BIIB021 was found to be $1.7 \pm 0.4$, better than that of 17-AAG (4.6 $\pm 0.5 \mathrm{nmol} / \mathrm{l})$ (30). The drug is selective for Hsp90 over kinases and another ATPase. Even at a low nanomolar concentration, BIIB021 can inhibit the growth of cancer cells, such as $\mathrm{N} 87, \mathrm{MCF}-7$ and $\mathrm{BT} 474$, with $\mathrm{IC}_{50}$ values ranging from 60 to $310 \mathrm{nmol} / \mathrm{l}$. It also exhibited antitumor effects in a xenograft model. As long as $48 \mathrm{~h}$ after treatment, the compound can be detected in tumor tissues despite its short half-life in serum. The effects of BIIB021 can last for more than $24 \mathrm{~h}$. This provides the possibility of flexible dose regimen to lessen dose-limiting hepatotoxicity. Furthermore, the cytotoxic activity of BIIB021 is not influenced by efflux pump, loss of NQO1 or Bcl-2 overexpression, avoiding the limitations of 17-AAG (31).

In conclusion, BIIB021 is a promising Hsp90 inhibitor. This review focuses on the utility of BIIB021 in a wide variety of cancers, especially in hematologic malignancies, and its underlying mechanisms. In addition, this review is followed by a discussion of current research on the application of Hsp90 inhibitors in blood malignancies.

\section{Effects of BIIB021 in hematologic malignancies}

Chronic myeloid leukemia. The majority of chronic myeloid leukemia (CML) cases are characterized by a fusion oncoprotein $(\mathrm{Bcr}-\mathrm{Abl})$ derived from the reciprocal translocation between chromosomes 9 and 22. Protein-tyrosine kinase expressed by this fusion protein activates several intracellular signaling pathways that prevent cells from apoptosis and promote cell proliferation. The introduction of tyrosine kinase inhibitors (TKIs) has dramatically improved the prognosis of CML patients. Yet, following the wide use of TKIs, almost $30 \%$ of patients have developed resistance to the standard treatment of imatinib. This phenomenon is attributed to mutations in the kinase domain, genomic instability and Bcr-Abl amplification, especially the T315I mutation even insensitive to the first and second generation of TKIs (32). The third generation TKIs, ponatinib, has antileukemia effect against CML cells with mutated Bcr-Abl including T315I. However, the risk of serious thromboembolic events restricts its application (33). Novel approaches therefore should be developed to override TKI resistance. Indeed, Bcr-Abl has been confirmed as a client protein of Hsp90 (34). Inhibitors of Hsp90 can destabilize the binding of Bcr-Abl protein thus resulting in formation of heteroprotein that is degraded via the ubiquitin proteasomal pathway (34).

A series of CML cell lines including T315I mutant were quite sensitive to BIIB021 (35). This drug inhibited cell proliferation and induced caspase-dependent apoptosis. Moreover, the oncoprotein Bcr-Abl was degraded and several signaling pathways were downregulated, including JAK/STAT and Akt. BIIB021 decreased the nuclear and cytoplasmic levels of $\beta$-catenin, a factor essential for survival and self-renewal of leukemic stem cells and blockage for the achievement of molecular remission in CML patients (36). Notably, BIIB021 triggered autophagy in CML cells independent of Beclin-1. 


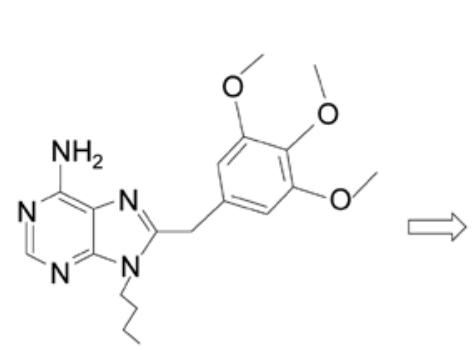

PU3

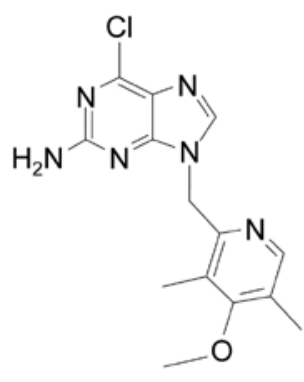

BIIB021
Figure 1. Chemical structures of PU-3 [9-butyl-8(3,4,5-trimethoxy-benzyl) -9H-purin-6-ylamine] and BIIB021 [6-chloro-9-[(4-methoxy-3,5-dimethyl-2-pyridinyl)methyl]- $9 H$-purin-2-amine].

Following exposure to BIIB021, the expression of Beclin-1 was decreased. This was contributed to activated caspase which cleaved Beclin-1 and the N-terminal fragment of Beclin-1 in turn suppressing autophagy $(37,38)$. In fact, BIIB021 targeted mTOR complex 1 to influence Ulk1 phosphorylation and eventually initiated autophagy. Pretreatment of autophagy inhibitor (3-methyladenine or bafilomycin A1) effectively increased the rate of BIIB021-mediated cell death and apoptosis. This suggested a possibility: BIIB021 combined with autophagy inhibitors in a regimen would achieve optimized therapeutic effect against imatinib-sensitive and -resistant CML, including cells harboring T315I-mutant Bcr-Abl.

Lymphomas. Lymphoma is one of the most frequently diagnosed human cancer. It may be divided into non-Hodgkin $(90 \%)$ and Hodgkin (10\%) subtypes. A total of $90 \%$ of lymphomas are of B-cell origin while some can be derived from T-cell or natural killer cells. Even though treatment of Hodgkin's lymphoma (HL) has already achieved great success, $2 \%$ of patients with HL are refractory to traditional therapy and $13 \%$ of patients suffer relapse (39). Hence, novel therapies are urgently needed. Current research indicates that Hsp90 is highly expressed in HL cells and promotes tumor survival by supporting the activation of NF- $\kappa \mathrm{B}$ signaling (40-42). One previous study illustrated that BIIB021 induces a decrease in $\mathrm{NF}-\kappa \mathrm{B}$ activity by $14-70 \%$ in HL cells with mutated I $\mathrm{B}$ or functional I $\mathrm{B}$. This means that BIIB021 inhibits the constitutionally active $\mathrm{NF}-\kappa \mathrm{B}$ in HL cells despite I $\kappa \mathrm{B}$ mutations. Moreover, Böll et al (43) observed that BIIB021 decreased HL cell viability and had additive effects with traditional chemotherapy (doxorubicin and gemcitabine). Furthermore, this type of Hsp90 inhibitor increased the susceptibility of HL cells against NK cell attack. Indeed, in response to BIIB021, researchers observed enhanced expression of NKG2D-specific ligands (MICA/B and ULBP2) on tumor cells. This in turn increased NK cell-related cytotoxicity of HL cells and may have a profound impact on the immune system and antitumor effects $(44,45)$. In accordance with the in vitro effects, BIIB021 also inhibited tumor growth in vivo.

In addition to HL, BIIB021 has shown efficacy against Kaposi sarcoma-associated herpes virus (KSHV)-associated primary effusion lymphoma (PEL) cells. PEL is a type of aggressive non-HL with poor prognosis. It is characterized by KSHV infection and frequently occurs in immunocompromised patients (46). Although a cytotoxic chemotherapeutic regimen is available to cure PEL, the prognosis of this disease is extremely poor and new therapeutic strategies must be found. Treatment with BIIB021 induced cell cycle arrest and apoptosis in PEL cells, by decreasing the level of several proteins critical for cell cycle regulation (CDK, c-MYC and cyclin) and pathogenesis of the disease (AKT, GSK3 $\beta$ and survivin) (47). As NF- $\kappa \mathrm{B}$ activity is essential for the survival and proliferation of PEL cells, researchers demonstrated that BIIB021 can block the constitutive NF- $\kappa \mathrm{B}$ pathway. On the one hand, BIIB021 reduced the level and activity of IKK $\alpha / \operatorname{IKK} \beta$ to influence the classical NF- $\kappa \mathrm{B}$ pathway. On the other hand, the Hsp90 inhibitor disrupted the K13-IKK complex resulting in downregulation of vFLIP and K13 and blockage of K13-related $\mathrm{NF}-\kappa \mathrm{B}$ activation. Moreover, the inability of BIIB021 to induce expression of lytic genes and inhibition of their expression alleviated the safety concern of lytic reactivation for KSHV lytic gene replication and transcription which are crucial to KSHV tumorigenesis. The antiproliferative effects were also evaluated in a mouse xenograft model. Compared with control vehicle, BIIB021 significantly reduced tumor volume and prevented development of splenomegaly.

More recently, it has emerged that BIIB021 is a candidate suppressor of latent membrane protein 1 (LMP1) expression which is a major oncogene encoded by the Epstein-Barr virus (EBV) (48). EBV can infect $\mathrm{B}$ cells, T cells and NK cells and is closely connected with immune cell malignancies. BIIB021 decreased the viability, induced apoptosis and caused cell cycle arrest of $\mathrm{T}$ and $\mathrm{NK}$ cell lines, including EBV-positive T cell lines (SNT13 and SNT16) and NK cell lines (KAI3 and SNK6). The drug also had a similar effect on Jurkat and KHYG1 which are EBV-negative counterparts. The protein level of LMP1 downstream targets was decreased, such as NF- $\kappa \mathrm{B}, \mathrm{JNK}$ and Akt. A murine xenograft model was used to demonstrate that BIIB021 can inhibit the growth of EBV-positive NK cell lymphomas in vivo.

T-cell acute lymphoblastic leukemia. T-cell acute lymphoblastic leukemia (T-ALL) is a clinically aggressive hematologic malignancy that accounts for $25 \%$ of adult ALL and $15 \%$ of pediatric cases (49). Limited targeting therapies are available for this type of disease at present. Li et al (50) reported that BIIB021 can inhibit the growth and induce the apoptosis of Molt-4 cells (a human T-ALL cell line) at low nanomolar concentrations. Notably, the drug disrupted the interaction between p53-MDM2 by suppressing the expression of MDM2 while increasing the level of $\mathrm{p} 53$. This resulted in $\mathrm{p} 53$-mediated apoptosis. Co-treatment with BIIB021 and triptolide (TPL) exhibited a synergetic inhibitory effect on the proliferation of Molt- 4 cells. This phenomenon may be because TPL can activate p53 without influence on MDM2 levels. Therefore, the co-treatment markedly enhanced p53 activation and upregulated the expression of several Bcl-2 family members (Bak and Bim).

Myelodysplastic syndrome. Researchers have previously reported that, compared with healthy subjects and low-risk myelodysplastic syndrome (MDS) patients, the level of Hsp90 is overexpressed in high-risk counterparts and is associated with a poor outcome. A preclinical trial examined the antitumor 
activity of BIIB021 on an MDS cell line (SKM-1) (51). Following BIIB021 treatment, SKM-1 cells were arrested in the G1 phase of the cell cycle and underwent apoptosis. Furthermore, the study also indicated that the mechanisms of apoptosis were attributed to a decrease in phosphatidylinositide 3-kinase/Akt and nuclear factor- $\mathrm{kB}$ pathway. All of the above findings imply that BIIB021 may be a new available strategy for high-risk MDS.

\section{Effects of BIIB021 in solid tumors}

Gastrointestinal stromal tumors. Gastrointestinal stromal tumors (GISTs) are one of the most common mesenchymal cancers of the digestive system (52). Activating mutations in KIT and PDGFR $\alpha$, two receptor tyrosine kinases, are the key element in the development and progression of GISTs. Specific mutations are associated with the therapeutic response to imatinib and sunitinib; however, most tumors ultimately become resistant to these drugs due to secondary kinase mutations or alternative activated pathways $(53,54)$. KIT and PDGFR $\alpha$ are client proteins of Hsp90 for their mutated forms rely on Hsp90 to stabilize (55). Inhibition of Hsp90 can result in the degradation of any form of these kinases. A phase II study evaluated the antitumor activity of BIIB021 in GIST patients (56). Twenty-three patients were stratified into two groups: 12 subjects received $600 \mathrm{mg}$ twice weekly (b.i.w.) while 11 subjects were administered $400 \mathrm{mg}$ three times weekly (t.i.w.). All patients had received prior treatment and had acquired resistance to imatinib and sunitinib. By evaluating the change from baseline (before day 1) to the end of one cycle (day 29), 5 patients had a decline of $>25 \%$ in SUVmax and achieved a partial response (PR). Among them, 3 of 12 patients $(25 \%)$ were from $600 \mathrm{mg}$ b.i.w. cohort and 2 of 11 patients (18\%) received $400 \mathrm{mg}$ t.i.w. Another 9 patients suffered a lower decrease in SUVmax although they did not meet the PR criterion. Moreover, the study also suggested that a more frequent dose of BIIB021 may induce better antitumor effect. The agent was generally well tolerated as most of the drug-related adverse events were less than grade 2. Compared with ansamycin derivatives such as IPI-504, treatment of BIIB021 did not induce severe hepatotoxicity.

Advanced solid tumors. Patients were treated with BIIB021 in a phase I dose-escalation trial with advanced solid tumors refractory to standard treatment (57). A total of 60 patients were enrolled in the study. The study determined the maximum tolerated dose (MTD) and safety of this Hsp90 inhibitor on two schedules: Twice a week for 3 weeks followed by 1 week off and twice a week for 4 weeks in continuous 28 day cycles. In schedule 1, 50 subjects were given a dose ranging from 25 to $800 \mathrm{mg}$ and BIIB021 was found to be well tolerated at doses up to $700 \mathrm{mg}$ twice a week. Dosed with $800 \mathrm{mg}$, two cases of dose-limiting toxicity (DLT) were observed: Syncope and dizziness. Based on the clinical information collected in schedule 1, 6 subjects received a dose of 600 and $700 \mathrm{mg}$ in schedule 2. An MTD was not established in this schedule formally, whereas the 6 patients tolerated these doses. The most common adverse events, defined as occurring in $>20 \%$ of patients, were nausea, hot flashes, vomiting and dizziness. These events were mild or moderate.
Kaposi sarcoma. Latency-associated nuclear antigen (LANA) is essential for Kaposi's sarcoma-associated herpesvirus (KSHV) genome persistence and Kaposi sarcoma (KS) tumorigenesis $(58,59)$. Recently, Chen et al $(60)$ determined that KSHV LANA is a client protein of Hsp90 and ATP-competitive Hsp90 inhibitors disrupted the association between Hsp90 and LANA for Hsp90 bound the N-terminal domain of LANA. This led to degradation of LANA through the ubiquitin-based proteasome pathway. Depletion of Hsp90 by shRNA induced the apoptosis of PEL cells. In vitro studies demonstrated that BIIB021 suppressed the proliferation of KS cells (SLK-KSHV, L1T2, SLK and KS-IMM) and decreased the expression of ephrin-B2 and EphA2 at low nanomolar concentrations. Remarkably, compared with KSHV-negative SLK cells, KSHV-positive counterparts were more sensitive to the Hsp90 inhibitor. Colony formation assays and cell cycle analysis further verified the antitumor potency of BIIB021. In addition, KSHV-infected L1T2 cells were injected into SCID mice to establish a xenograft KSHV tumor model. Compared to the negative control, the growth of tumors was notably retarded following treatment of Hsp90 inhibitor (AUY922) at a dose of $50 \mathrm{mg} / \mathrm{kg}$. Immunohistochemistry showed declined levels of LANA and ephrin-B2.

Squamous cell carcinoma. Every year, there are $\sim 600,000$ newly diagnosed cases of head and neck squamous cell carcinoma (HNSCC) reported. At present, the standard treatment includes surgery and/or radiotherapy. Radiotherapy is mainly applied to patients with advanced disease and chemotherapy is concomitantly used to increase the efficacy. Recently, BIIB021 has been found as a new adjuvant agent that enhances the sensitivity of HNSCC cell lines to radiation (61).

BIIB021 showed better anti-proliferative effects in 4 cell lines with a mean $\mathrm{IC}_{50}$ value of $250 \mathrm{nM}$, superior to 17-AAG. Compared with each treatment alone, co-treatment with BIIB021 effectively increased the radiation-related cell death and apoptosis even in radiation-resistant cell lines, by downregulating several oncogenic proteins including EGFR, c-Raf-1 and Akt. Moreover, BIIB021 enhanced the G2/M cell population in response to radiotherapy independent of the p53 status.

In xenograft models, the tumors grew much smaller in the combination arm. Tumor sizes remained stabilized following 3 weeks of treatment with BIIB021 or radiation alone while the volume of tumors showed regression after 4 weeks with the combination treatment.

Furthermore, BIIB021 potentiated a significant therapeutic window of radiation to esophageal squamous cell carcinoma cell lines by influencing apoptosis and the cell cycle (62). BIIB021 dramatically decreased the levels of radio-resistance-related proteins such as EGFR, Akt and Raf-1.

Thyroid carcinoma. Although well-differentiated thyroid carcinoma (WDTC) is a type of tumor associated with a good prognosis, 2/3 of cases of metastatic WDTC are refractory. Meanwhile, patients with anaplastic thyroid carcinoma exhibit poor outcome as the tumors are highly aggressive. Recently, research illustrated that BIIB021 induced the cell death of thyroid carcinoma cell lines (8505C and TPC-1) by degrading Hsp90 client proteins. Furthermore, cotreatment 
with BIIB021 and histone acetyltransferase inhibitor triptolide demonstrated a combined effect in regards to cytotoxicity induction. This synergism was contributed to inhibition of the $\mathrm{PI} 3 \mathrm{~K} / \mathrm{Akt} / \mathrm{mTOR}$ and NF- $\mathrm{KB}$ signaling pathways, a decrease of survivin, xIAP and cIAP and promotion of DNA damage (63).

\section{Targeting Hsp90 in hematologic malignancies}

The promising antitumor potency of BIIB021 in leukemia and lymphoma motivates the focus of this inhibitor for the treatment of blood malignancies by targeting Hsp90.

A high level of Hsp90 has been observed in leukemia and myeloma (64-67). The Hsp90 level in plasma can be used as a biomarker of leukemia engraftment and progression (68). Overexpression of the protein is correlated with poor prognosis and chemotherapy resistance in acute myeloid leukemia (AML) (69). Furthermore, Hsp90 is required to maintain the stability and function of oncogenic proteins such as c-KIT and FLT3-ITD in AML and Bcr-Abl in CML (70). Inhibition of Hsp90 extensively influences a variety of signaling proteins involved in cell apoptosis, survival and differentiation. Hence, it is reasonable to use Hsp90 inhibitors for the treatment of hematologic malignancies.

\section{Preclinical studies}

Control of apoptosis and cell cycle. Treatment with Hsp90 inhibitors could induce apoptosis by activating the mitochondrial caspase pathway and regulating Bcl-2 family proteins $(50,71)$.

In diffuse large B-cell lymphoma (DLBCL), endogenous Hsp90 interacts with $\mathrm{Bcl} 6$ and stabilizes Bcl6 at both the transcription and protein level. Apoptosis was observed after treatment with the Hsp90 inhibitor, PU-H71. The drug preferentially accumulated in lymphomas and suppressed Bcl6-dependent DLBCL xenografts (72). Recently, a novel oncogenic pathway was found which promotes the aberrant survival of T-ALL cells, i.e. tyrosine kinase 2 (TYK2)/phospho-STAT1/Bcl2 pathway (73). TYK2, as a member of the JAK tyrosine family, is a client protein of Hsp90 (74,75). An Hsp90 inhibitor NVP-AUY922 effectively degraded TYK2 and resultantly decreased phospho-STAT1 and $\mathrm{Bcl} 2$, a pro-survival protein. Meanwhile, the drug increased pro-apoptotic proteins Bim and Bad (76).

Furthermore, Hsp90 inhibitors are able to regulate the cell cycle. Mantle cell lymphoma (MCL) is characterized by the overexpression of cyclin D1 and abnormal regulation of the cell cycle. Treatment with Hsp90 inhibitors induced G0/1 arrest in MCL cells and decreased cell cycle regulatory proteins, including cyclin D1, cdk4, p21 and CHK1 (77,78).

Degradation of oncoprotein and disruption of signaling transduction. FLT3-ITD and point mutation occur in 25-30\% of AML patients and are associated with poor prognosis. Meanwhile, FLT3-ITD is a client protein of Hsp90. 17-AAG induced polyubiquitination and proteasomal degradation of FLT3-ITD and mutants by disrupting its association with Hsp90 (79,80). Downstream signaling of FLT3-ITD such as JAK-STAT and PI3K/AKT was also decreased (81). In addition, $5 \%$ of AML patients have KIT mutations and activated KIT kinase plays an essential role in the pathophysiology of the disease (82). 17-AAG and GA were found to suppress the growth of cells expressing D816V-KIT (83).

The oncoprotein Bcr-Abl is involved in the pathogenesis of $\mathrm{Bcr}_{-} \mathrm{Abl}^{+}$human leukemia including $\mathrm{CML}$ and $\mathrm{Ph}^{+} \mathrm{ALL}$. Bcr-Abl is a client protein of Hsp90, and Hsp90 inhibitors have been developed as novel approaches for the treatment of Bcr-Abl ${ }^{+}$leukemia especially in relapsed or IM-resistant cases. Hsp90 inhibitors were found to induce Bcr-Abl degradation and this was accompanied by inhibition of downstream signaling (JAK/STAT, Akt and $\beta$-catenin) including cells expressing T315I mutation $(35,84,85)$. A novel Hsp90 inhibitor IPI-504 was found to effectively inhibit the survival and proliferation of leukemic stem cells which is a potential reason for relapse (86). The drug prolonged the survival period of mice bearing Bcr-Abl T315I-induced leukemia. In addition, Hsp90 inhibitors exerted a combined effect with TKIs $(87,88)$.

Bcr-Abl-negative myeloproliferative neoplasms (MPNs) are a group of stem cell diseases that include polycythemia vera, essential thrombocytosis and primary myelofibrosis. In the majority of patients with MPNs, a mutation in the JAK2 kinase $(J A K 2$ V617V) is always detected with constitutive activation of the JAK2-STAT pathway which is independent of growth factors. This allows hematopoietic cell proliferation in the absence of cytokines. However, JAK2 inhibitors show limited efficacy in the clinic. Hsp90 inhibitors have been evaluated for the treatment of MPNs in preclinical studies, considering JAK2 is a client protein of Hsp90. PU-H71, a new Hsp90 inhibitor, induced degradation of JAK2, inhibited JAK-STAT signaling and triggered cell apoptosis in JAK2 mutant cell lines and primary patient samples. PU-H71 also had the potency to improve the survival period in mouse bone marrow transplant models by disrupting JAK2 stability, without toxic effects on normal hematopoiesis (89).

As the most common leukemia in the Western world, $\mathrm{B}$-cell CLL is a malignancy of mature B cells expressing T-cell antigen CD5. The disease is characterized by elevated expression of several Hsp90 client proteins making Hsp90 a potential therapeutic target. At the molecular level, Hsp90 inhibitors led to depletion of Akt, IKK and NF- $\kappa \mathrm{B}$, accompanied by a decline in NF- $\kappa \mathrm{B}$ target gene (MCL1, CFLAR, BIRC5 and BCL2) transcription and apoptosis in a caspase-dependent manner $(90,91)$. Compared with normal B lymphocytes, Lyn is overexpressed, abnormally exists in the cytosol of B-CLL and shows high activity which mediates signaling cascade triggered by BCR. As Hsp90 binds to the catalytic domain of Lyn, treatment with GA triggers the cytosolic Lyn complex destabilizes in the early phases of apoptosis and resultantly inactivates cytosolic Lyn (92). Recently, research indicated that SOCS3 acts as a regulator of important cell survival pathways in CLL. By activation of p38 signaling, 17-DMAG increased the SOCS3 level and in turn prohibited phosphorylation of AKT and STAT3, thus inducing blockage of cell migration and survival in CLL (93).

Adult T-cell leukemia-lymphoma (ATL) is a chemoresistant malignancy with an origin from $\mathrm{CD} 4^{+} \mathrm{CD} 25^{+}$ T lymphocytes linked to HLTV-1. Tax, encoded by the HTLV-1 genome, can control HTLV-1 replication and advance oncogenic transformation of $\mathrm{T}$ lymphocytes. Recently, research indicated that Hsp90 is a binding partner of Tax. Downregulation of Hsp90 by 17-DMAG or shRNAs provoked 
Tax degradation and this was accompanied by attenuation of NF- $\kappa \mathrm{B}$ and HTLV-1 LTR activation. Thus, 17-DMAG suppressed HTLV-1 replication and led to apoptosis in cell lines and primary ATL cell samples $(94,95)$. The drug has no apparent effects on normal PBMCs. In addition, PIM kinases and the $\beta$-catenin/TCF7L2 pathway underwent a decrease and resultantly these contributed to Hsp90 inhibitor-associated cell apoptosis in ALT cells $(95,96)$. In an ATL mouse model, 17-DMAG administration reduced infiltration of tumor cells into organs, inhibited de novo viral production and prolonged the survival period (97).

Abrogation of micro-environment protection. Hematological malignancies always develop in the bone marrow and secondary lymphoid organs. These microenvironments are characterized by various stromal and $\mathrm{T}$ cells that are essential to cancer cell survival and drug resistance. Microenvironment-targeted treatment has emerged and gained attention in hemato-oncology.

In multiple myeloma (MM), 17-AAG suppressed the expression of IGF1R andIL-6R on the cell surface and their downstream signaling including IKK/NF- $\kappa \mathrm{B}, \mathrm{PI}-3 \mathrm{~K} / \mathrm{Akt}$ and Raf/MAPK. Such effects abrogated the protection of bone marrow stromal cells (BMSCs) on MM tumor cells and made them sensitive to other anticancer agents (66). Furthermore, treatment with SNX-2112 was able to overcome the protective effects derived from cytokines and BMSCs. This is because SNX-2112 inhibited Akt and MEK/ERK pathway even in the presence of exogenous IL-6, IGF-1, or BMSCs and block the formation of capillary-like tubes by suppression of eNOS/Akt. In addition, as osteolytic bone destruction is a common complication of MM, SNX-2112 has the potency to markedly inhibit osteoclastogenesis by downregulation of ERK/c-fos and PU.1 (98). Exposure of Hsp90 inhibitor (KW-2478) to MM cells induced a decrease in IgH translocation products (FGFR3, c-Maf and cyclin D1). In a MM orthotopic model, KW-2478 not only decreased the $\mathrm{M}$ protein level in serum but also reduced tumor burden in bone marrow (99).

Within bone marrow and lymph nodes, CLL cells are mixed with numerous $\mathrm{T}$ lymphocytes expressing CD40 ligand and IL-4. Together with BMSCs and follicular dendritic cells, these cells can protect CLL cells from chemotherapy-related apoptosis in vitro. Co-cultured CLL cells with NTL or CD40L cells abrogated fludarabine's ability to kill cells and dasatinib resistance also occurred in NTL or CD154L/IL-4 co-culture system. By comparison, Hsp90 inhibitor NVP-AUY922-AG retained its toxicity under the same condition by decreasing IKK $\alpha, \operatorname{IKK} \beta$, regulators of $N F-\kappa B$, and retarding the transcription of NF- $\kappa \mathrm{B}$ target genes MCL1, CFLAR and BIRC5. Considering fludarabine activation of MCL1 and BIRC5, Walsby et al (91) treated NVP-AUY922 with fludarabine and found that this Hsp90 inhibitor potentiated CLL cell sensitivity to fludarabine. This combination maintained the net transcriptional repression of MCL1, CFLAR and BIRC5, providing a potential explanation for the synergy. The same synergistic effect was also observed following cotreatment of 17-DMAG with dasatinib (100).

Overcoming drug resistance. Initially, there is only a minority of CLL patients at diagnosis who present with TP53 mutation or deletion. However, such defects are frequently obtained during the disease course and induced p53 defects are strongly associated with resistance to alkylating agents and purine analogues, the mainstay of current treatment. Treatment with GA depressed the overexpressed mutant p53 protein while increased the level of wt counterparts. These phenomena were ATM-independent and linked to a decrease in Akt and activation of MDM2. p21, a potent inducer of cell cycle arrest, was upregulation without dependence of p53/ATM. Cytotoxicity studies demonstrated that Hsp90 inhibitors prohibited the proliferation of cell lines and patient samples $(101,102)$. It was suggested that Hsp90 inhibitor abrogated chemo-resistance in CLL with TP53 defects for it killed cells independent of ATM or TP53 mutations. Furthermore, SNX-7081, a synthetic Hsp90 inhibitor, synergized with fludarabine against CLL cells as evidenced by a significant reduction in the $\mathrm{IC}_{50}$ value of fludarabine to within a clinically achievable range and a decrease in cell viability (103).

As described above, inhibitors of JAK2 have been developed for the treatment of MPNs, CRLF2-rearranged B-ALL and other tumors with activated JAK2 signaling. Research has indicated that cells expressing G935R, Y931C and E864K mutations near the ATP-binding region of the JAK2 kinase are resistance to a panel of JAK inhibitors, whereas, these mutations had little influence on tumor cell sensitivity to Hsp90 inhibitors. In fact, AUY922 degraded both wild-type and mutant type of JAK2. AUY922 also exhibited 100- to 1,000-fold more potency against B-ALL cells harboring CRLF2 rearrangements than an enzymatic JAK2 inhibitor for the Hsp90 inhibitor has multi-targets (104).

Eradication of stem cells. Cancer stem cells (CSCs) are a subpopulation of cancer cells with properties of quiescence, self-renewal and persistent proliferation. CSCs are the key contributors to drug resistance as well as relapse and metastasis (105).

At low concentrations, 17-AAG has the ability to eliminate lymphoma stem cells in vitro and in vivo, as the drug disrupts Hsp90-mediated mRNA expression and transcriptional activity of HSF1 $\alpha$ (106). Peng et al (86) isolated bone marrow cells from mice with CML expressing T315I and showed that treatment with IPI-504 had a marked inhibitory effect on stem cells while IM had little influence. Efficacious anti-CSC potency of IPI-504 was also observed in mouse models without inhibition of normal CSCs. Hsp90 inhibitor decreased $\beta$-catenin, a factor essential for survival and self-renewal of leukemic stem cells (36). In addition, co-treatment with Hsp90 inhibitor and SIRT1 inhibitor exhibited a combined effect on chemo-resistant stem-like cells of CML (107). Depletion of SIRT1 prohibited the 17-AAG-mediated induction of Hsp70/Hsp27 and BCRP-mediated activity of 17-AAG efflux and reduced the levels of CD44, Oct-4, $\beta$-catenin, c-Myc and mut-p53.

Combined effects. Hsp90 inhibitors exert a synergistic effect together with traditional or targeted chemotherapeutic agents including doxorubicin, bortezomib, PI3K inhibitor, Akt inhibitor, IBP inhibitor, rapamycin and HDACi (108-113). Recently, it was found that PU-H71 can target BCR signaling, and subsequently attenuate kinase phosphorylation, calcium signaling and NF- $\mathrm{B}$ activity. Combined exposure to PU-H71 
Table I. Reported clinical studies of Hsp90 inhibitors in blood malignancies.

\begin{tabular}{|c|c|c|c|c|c|}
\hline Blood malignancies & Hsp90 inhibitor & Phase & Patient no. & DLTs & Findings \\
\hline Acute leukemia & 17-DMAG & I & 24 & Cardiac ischemia & $\begin{array}{l}\text { MTD was } 24 \mathrm{mg} / \mathrm{m}^{2} \text { twice } \\
\text { weekly; } 3 / 17 \text { achieved CR with } \\
\text { incomplete blood count recovery }\end{array}$ \\
\hline B cell malignancies & KW-2478 & I & $\begin{array}{l}27(22 \mathrm{MM} \\
\text { and } 5 \mathrm{nNL})\end{array}$ & No DLTs & $\begin{array}{l}\text { MTD was not reached; } \\
24 / 25(96 \%) \text { achieved } \\
\text { SD with } 5 \text { being free of disease } \\
\text { progression for } \geq 6 \text { months }\end{array}$ \\
\hline Relapsed lymphoma & 17-AAG & II & $\begin{array}{l}22(13 \mathrm{cHL} \\
\text { and } 9 \mathrm{MCL})\end{array}$ & - & $\begin{array}{l}7 / 18(39 \%) \text { demonstrated tumor } \\
\text { reduction, } 2 / 18 \text { achieved PR }\end{array}$ \\
\hline CLL & 17-DMAG & $\mathrm{I}$ & 15 & No DLTs & $\begin{array}{l}\text { MTD was not reached, } 3 / 15 \\
\text { achieved SD }\end{array}$ \\
\hline nHL & AUY922 & II & $\begin{array}{l}20 \text { (14 DLBCL } \\
\text { and } 6 \text { PTCL) }\end{array}$ & - & $\begin{array}{l}1 / 14 \text { achieved CR in DLBCL } \\
\text { and } 1 / 6 \text { achieved PR in PTCL; } \\
13 / 20 \text { received only } 1 \text { cycle of } \\
\text { AUY } 922 \text { or less due to apparent } \\
\text { disease progression }\end{array}$ \\
\hline MM & NVP-AUY922 & $\mathrm{I}$ & 24 & Blurred vision & $\begin{array}{l}\text { No MTD was reached, 16/24 } \\
\text { had SD }\end{array}$ \\
\hline MM & $\begin{array}{l}\text { 17-AAG+ } \\
\text { bortezomib }\end{array}$ & $\mathrm{I} / \mathrm{II}$ & 72 & $\begin{array}{l}\text { Hepatotoxicity, } \\
\text { renal failure, } \\
\text { metabolic acidosis }\end{array}$ & $\begin{array}{l}\text { MTD was } 17-\mathrm{AAG} 340 \mathrm{mg} / \mathrm{m}^{2} \\
\text { and bortezomib } 1.3 \mathrm{mg} / \mathrm{m}^{2} ; 2 / 67 \\
\text { achieved CR, } 8 / 67 \text { achieved } \\
\text { PR, } 8 / 67 \text { had a minimal response } \\
\text { and } 22 / 67 \text { had SD }\end{array}$ \\
\hline MM & $\begin{array}{l}\text { NVP-AUY922+ } \\
\text { bortezomib }\end{array}$ & IB & 5 & $\begin{array}{l}\text { Musculoskeletal pain, } \\
\text { diarrhea, atypical } \\
\text { noncardiac chest and } \\
\text { musculoskeletal pain }\end{array}$ & 1/5 had PR, $4 / 5$ had SD \\
\hline Acute leukemia & 17-AAG+ Ara-C & I & 26 & $\begin{array}{l}\text { DIC, ARDS, } \\
\text { myocardial infarction }\end{array}$ & $\begin{array}{l}\text { MTD was Ara-C } 400 \mathrm{mg} / \mathrm{m}^{2} / \text { day } \\
\text { for } 5 \text { days along with } 17-\mathrm{AAG} \\
300 \mathrm{mg} / \mathrm{m}^{2} \text { on days } 3 \text { and } 6 ; 2 / 21 \\
\text { had } \mathrm{CR}, 4 / 21 \text { had PR }\end{array}$ \\
\hline
\end{tabular}

DLT, dose-limiting toxicity; MTD, maximum tolerated dose; MM, multiple myeloma; nNL, non-Hodgkin lymphoma; cHL, classical Hodgkin lymphoma; MCL, mantle cell lymphoma; PR, partial response; CLL, chronic lymphocytic leukemia; DLBCL, diffuse large B-cell lymphoma; PTCL, peripheral T-cell lymphoma; CR, complete response; Ara-C, cytarabine; SD, stable disease; DIC, disseminated intravascular coagulation; ARDS, adult respiratory distress syndrome.

and ibrutinib, a BCR pathway inhibitor, induced synergistic killing of DLBCL cell lines (114).

Bortezomib has been introduced to the treatment of relapsed/refractory MCL for it can induce cell death through upregulation of the $\mathrm{BH} 3$-only proapoptotic protein Noxa and generation of reactive oxygen species rather than dependence on the NF- $\kappa \mathrm{B}$ pathway, whereas, not all patients respond to the drug and resistance often appears. Based on an analysis of 18 MCL samples, Roue et al (115) found that these phenomena may result from an increase in pro-survival chaperone Bip/Grp78 of which stabilization is dependent on Hsp90. Simultaneous exposure to IPI-504 and bortezomib abrogated the association between Hsp90 and Bip, then activated the ER stress pathway and ultimately restored MCL cell sensitivity to bortezomib both in vitro and in vivo. This combination deserves further research at the clinical level.

In primary AML blasts, the 50\% lethal dose of Hsp90 inhibitor (NVP-AUY922-AG) was observed at concentrations 2 logs lower than cytarabine (Ara-C) which is a traditional chemotherapy agent. There was a synergistic decrease in the proliferation of AML cells and 20/25 primary samples following co-treatment with the two agents $(116,117)$. This was due to the fact that Ara-C, even at low concentrations, induced activation of Chk1 which facilitated cell survival. Conversely, following treatment of 17-AAG for $24 \mathrm{~h}$, the expression of Chk1 was depleted. This was accompanied by diminished Ara-C-related S phase accumulation and decreased Cdc25A degradation (118). 


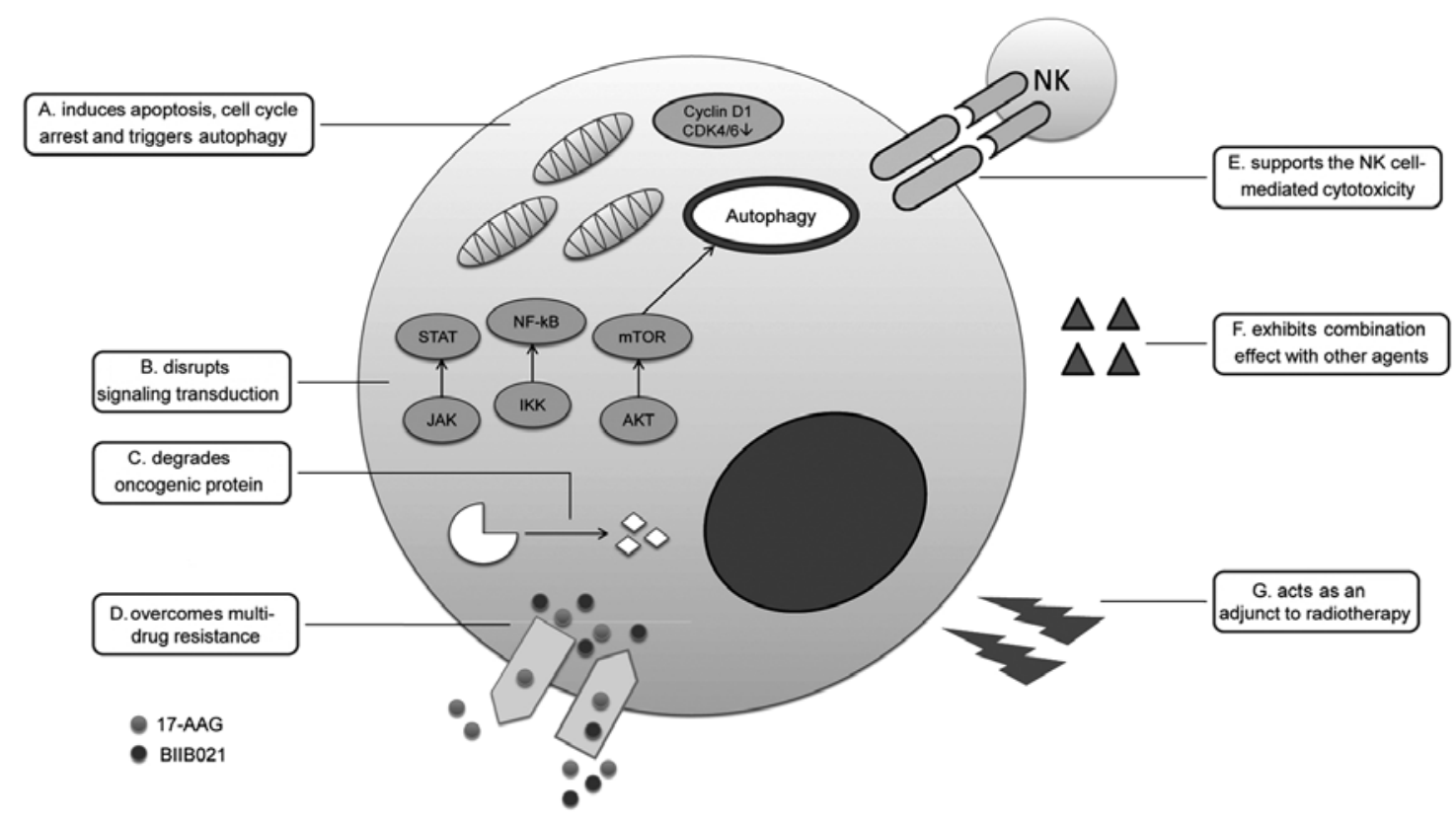

Figure 2. Mechanisms underlying the effects on cancer cells by BIIB021. BIIB021 induces apoptosis, cell cycle arrest and triggers autophagy of tumor cells (A). Treatment with BIIB021 disrupts signaling transduction (B), leads to degradation of oncogenic protein (C), overcomes multidrug resistance (D), supports NK cell-mediated cytotoxicity (E), acts as an adjunct to radiotherapy (G) and exhibits a combined effect with other agents (F).

Clinical trials. As the preclinical data suggest that Hsp90 inhibitors have anticancer activity via multiple mechanisms and are an attractive therapeutic strategy, clinical trials have been conducted to evaluate their MTD, safety and pharmacokinetic properties (Table I).

In a phase I study, 24 patients with advanced AML were enrolled and received escalating doses of 17-DMAG. This type of Hsp90 inhibitor was well tolerated with toxicities of neutropenic, fever, fatigue, nausea and diarrhea. The MTD recommended was $24 \mathrm{mg} / \mathrm{m}^{2}$ on a twice-weekly dosing schedule. Two cases of cardiac DLT were observed at $32 \mathrm{mg} / \mathrm{m}^{2}$. Compared with baseline, the apoptosis increased within leukemic marrow $\mathrm{CD} 34^{+}$cells at day 15 . Evidence of 17-DMAG antitumor activity included three patients which achieved a complete response (CR) with incomplete blood count recovery (CRi) and one had a $>50 \%$ bone marrow blast reduction. Notably, among the 3 patients who had CRi, 2 showed del(7q) karyotype (119). Whereas, another phase I study indicated that 17-AAG had limited synergistic activity with Ara-C at clinically tolerable doses. Among 21 patients, 2 achieved CR and 4 had PR. The drug combination induced serious adverse effects: Disseminated intravascular coagulation (DIC), acute respiratory distress syndrome (ARDS) and myocardial infarction. A modest downregulation of Chk1 and other Hsp90 client proteins was observed. This may have resulted from Hsp70 upregulation caused by the two drugs and, at clinical tolerated dose, time was limited to sustain effective concentrations of 17-AAG that were able to downregulate substantial client proteins in vivo (120). Other Hsp90 inhibitors with reduced toxicity, better solubility and improved pharmacokinetics and pharmacodynamics should be developed and used in the treatment of AML.

The oncogenic process of multiple myeloma (MM) is not driven by classical client proteins of Hsp90. However, Hsp90 plays a critical role in the regulation of MM cell proliferation, survival, drug resistance and microenvironmental interactions. In a phase I/IB study, 24 patients with relapsed or refractory MM received NVP-AUY922 at doses ranging from 8 to $70 \mathrm{mg} / \mathrm{m}^{2}$. At $70 \mathrm{mg} / \mathrm{m}^{2}$, grade 3 blurred vision was observed while no MTD was reached. None of the patients achieved CR or PR. A total of 16/24 of the subjects had stable disease (SD). Another non-ansamycin, non-purine Hsp90 inhibitor, KW-2478, was administered intravenously in a phase I study in a dose range of 14 to $176 \mathrm{mg} / \mathrm{m}^{2}$ and was well tolerated without DLTs. A total of 20 (95.2\%) patients achieved SD among 24 evaluable patients (121). As in vitro and animal experiments suggest that $17-\mathrm{AAG}$ synergizes with standard therapy bortezomib, a phase I/II clinical trial enrolled 72 patients with relapsed or refractory MM to assess the combined effect. On days 1, 4, 8 and 11 in each 21-day cycle, patients received 17-AAG $\left(100-340 \mathrm{mg} / \mathrm{m}^{2}\right)$ and bortezomib $\left(0.7-1.3 \mathrm{mg} / \mathrm{m}^{2}\right)$ in a phase I study while $17-\mathrm{AAG}$ $\left(340 \mathrm{mg} / \mathrm{m}^{2}\right)$ plus bortezomib $\left(1.3 \mathrm{mg} / \mathrm{m}^{2}\right)$ was administered during the phase II expansion. Among the evaluable 67 patients, 2 patients $(3 \%)$ had CR, 8 patients $(12 \%)$ had PR, 8 patients $(12 \%)$ had a minimal response and 22 patients (33\%) experienced SD (122). Prior exposure and response to bortezomib dramatically influenced the response rates; the highest rates were in bortezomib-naive patients $(10 / 21 ; 48 \%)$.

Hsp90 is commonly expressed in many types of B- and T-cell lymphoma and its client proteins are critical in cell proliferation and survival $(40,67)$. Hence, many lymphoma types are suitable targets for Hsp90 inhibitors and clinical trials were also conducted to examine the effects of Hsp90 inhibitors on lymphoma. In a phase II study, 22 patients with relapsed lymphoma were enrolled and received 17-AAG at $220 \mathrm{mg} / \mathrm{m}^{2}$. Seven of 18 patients suffered tumor reduction of whom 2 had PR (123). The biopsy specimens of MCL showed, after treatment of 17-AAG, the expression of p-AKT, cyclin D1 and Ki-67 declined while activation of caspase-3 
increased. In addition, another open-label, single arm phase II study evaluated the efficacy of AUY922 against DLBCL and peripheral T-cell lymphoma (PTCL). After 2 cycles, 1/14 DLBCL patients achieved a CR and 1/6 PTCL patients achieved PR (124).

\section{Conclusion}

In an era of precision medicine, clinicians are able to design optimal therapies for patients with malignant tumors according to molecular analyses. Hsp90 inhibitors are a type of agents that target oncogenic proteins and signaling networks in several tumors by influencing protein post-translational maturation and disposition. Unfortunately, the clinical potency of first generation Hsp90 inhibitors is limited as natural product derivatives are toxic and have unfavorable pharmacokinetic properties.

BIIB021, as a fully synthetic small-molecule inhibitor, has shown effective antitumor potency. In vitro experiments have demonstrated that it induces apoptosis, cell cycle arrest and triggers autophagy of tumor cells. Treatment with BIIB021 led to degradation of oncogenic proteins, disrupted signaling transduction, supported NK cell-mediated cytotoxicity, acted as an adjunct to radiotherapy, overcame multi-drug resistance and exhibited combined effects with other agents (Fig. 2). Furthermore, this agent has advantages of good solubility and low toxicity. phase I/II trials indicate that the drug is active in serum, PBMCs and tumor tissue, is well tolerated and could lead to objective responses in refractory GIST patients $(56,57)$. BIIB021 is a promising Hsp90 inhibitor that deserves further studies in regards to the treatment of patients with refractory or relapsed tumors especially in blood malignancies.

The efficacy of BIIB021 against leukemia and lymphoma allows us to focus on using this Hsp90 inhibitor in the treatment of blood malignancies. Indeed, the expression level of Hsp90 is high and is correlated with poor prognosis in leukemia and myeloma (64-67). Inhibition of Hsp90 can result in degradation of its client protein including Bcr-Abl, c-KIT and FLT3-ITD which are oncoproteins or constitutively activated in leukemia.

Pre-clinical data demonstrated that Hsp90 inhibitors lead to apoptosis of cancer cells by varied mechanisms. Clinical trials have demonstrated that Hsp90 inhibitors can enable a population of patients with relapsed or refractory blood malignancies to achieve CR, PR or SD $(119,123,125)$ (Table I). However, single treatment with an Hsp90 inhibitor showed limited activity against various diseases (124). One potential solution may be combination therapy. Several in vitro studies have provided rationale for combining Hsp90 inhibitor with a number of other agents, including Ara-C, bortezomib, imatinib, histone deacetylase inhibitor and FLT3 inhibitor. In a phase I/II trial, 17-AAG + bortezomib were well tolerated and $27 \%$ patients with relapsed or refractory myeloma achieved objective response (122). In another phase I study, after exposure to $17-\mathrm{AAG}+\mathrm{Ara}-\mathrm{C}$, the overall response rate was $23 \%$ among 26 patients with relapsed and refractory acute leukemia (120). At tolerable doses, the time of 17-AAG for effective concentration was insufficient to decrease client proteins. This may contribute to the limited combination activity. It is expected that more clinical studies can be conducted to search for synergistic effects by using novel Hsp90 inhibitors with favorable pharmacologic properties.

In summary, BIIB021 is a novel agent in the fight against cancer and targeting Hsp90 is a promising therapeutic strategy for the management of blood malignancies.

\section{Acknowledgements}

Not applicable.

\section{Funding}

The present study was supported by Funds of the Medical and Health Science Project of Zhejiang Province (no. 2017ZD029).

\section{Availability of data and materials}

All data generated or analyzed during this study are included in this published article.

\section{Authors' contributions}

WH conceived and designed the study. WH and $\mathrm{HXH}$ researched the literature, performed analysis of data and drafted the manuscript. Both authors read and approved the manuscript and agree to be accountable for all aspects of the research in ensuring that the accuracy or integrity of any part of the work are appropriately investigated and resolved.

\section{Ethics approval and consent to participate}

Not applicable.

\section{Consent for publication}

Not applicable.

\section{Competing interests}

The authors state that they have no competing interests.

\section{References}

1. Amolins MW and Blagg BS: Natural product inhibitors of Hsp90: Potential leads for drug discovery. Mini Rev Med Chem 9: 140-152, 2009.

2. Wang X, Chen M, Zhou J and Zhang X: HSP27, 70 and 90 , anti-apoptotic proteins, in clinical cancer therapy (Review). Int J Oncol 45: 18-30, 2014

3. Whitesell L and Lindquist SL: HSP90 and the chaperoning of cancer. Nat Rev Cancer 5: 761-772, 2005.

4. Scaltriti M, Dawood S and Cortes J: Molecular pathways: Targeting hsp90-who benefits and who does not. Clin Cancer Res 18: 4508-4513, 2012.

5. Mori M, Hitora T, Nakamura O, Yamagami Y, Horie R, Nishimura $\mathrm{H}$ and Yamamoto T: Hsp90 inhibitor induces autophagy and apoptosis in osteosarcoma cells. Int J Oncol 46: 47-54, 2015.

6. Hernandez MP, Chadli A and Toft DO: HSP40 binding is the first step in the HSP90 chaperoning pathway for the progesterone receptor. J Biol Chem 277: 11873-11881, 2002.

7. Pratt WB, Galigniana MD, Morishima Y and Murphy PJ: Role of molecular chaperones in steroid receptor action. Essays Biochem 40: 41-58, 2004. 
8. Chandarlapaty S, Scaltriti M, Angelini P, Ye Q, Guzman M Hudis CA, Norton L, Solit DB, Arribas J, Baselga J and Rosen N: Inhibitors of HSP90 block p95-HER2 signaling in Trastuzumab-resistant tumors and suppress their growth. Oncogene 29: 325-334, 2010.

9. Scaltriti M, Serra V, Normant E, Guzman M, Rodriguez O, Lim AR, Slocum KL, West KA, Rodriguez V, Prudkin L, et al: Antitumor activity of the Hsp90 inhibitor IPI-504 in HER2-positive trastuzumab-resistant breast cancer. Mol Cancer Ther 10: 817-824, 2011

10. Chen Y, Sawyers CL and Scher HI: Targeting the androgen receptor pathway in prostate cancer. Curr Opin Pharmacol 8: 440-448, 2008.

11. Vanaja DK, Mitchell SH, Toft DO and Young CY: Effect of geldanamycin on androgen receptor function and stability. Cell Stress Chaperones 7: 55-64, 2002.

12. Chapman PB, Hauschild A, Robert C, Haanen JB, Ascierto P Larkin J, Dummer R, Garbe C, Testori A, Maio M, et al: Improved survival with vemurafenib in melanoma with BRAF V600E mutation. N Engl J Med 364: 2507-2516, 2011.

13. da Rocha Dias S, Friedlos F, Light Y, Springer C, Workman P and Marais R: Activated B-RAF is an Hsp90 client protein that is targeted by the anticancer drug 17-allylamino-17-demethoxygeldanamycin. Cancer Res 65: 10686-10691, 2005.

14. Haigis KM, Kendall KR, Wang Y, Cheung A, Haigis MC, Glickman JN, Niwa-Kawakita M, Sweet-Cordero A, Sebolt-Leopold J, Shannon KM, et al: Differential effects of oncogenic K-Ras and N-Ras on proliferation, differentiation and tumor progression in the colon. Nat Genet 40: 600-608, 2008.

15. Davies H, Bignell GR, Cox C, Stephens P, Edkins S, Clegg S, Teague J, Woffendin $\mathrm{H}$, Garnett MJ, Bottomley W, et al: Mutations of the BRAF gene in human cancer. Nature 417: 949-954, 2002

16. Shimamura T, Lowell AM, Engelman JA and Shapiro GI: Epidermal growth factor receptors harboring kinase domain mutations associate with the heat shock protein 90 chaperone and are destabilized following exposure to geldanamycins. Cancer Res 65: 6401-6408, 2005.

17. Shiotsu Y, Soga $S$ and Akinaga S: Heat shock protein 90-antagonist destabilizes Bcr-Abl/HSP90 chaperone complex. Leuk Lymphoma 43: 961-968, 2002.

18. Castro JE, Prada CE, Loria O, Kamal A, Chen L, Burrows FJ and Kipps TJ: ZAP-70 is a novel conditional heat shock protein 90 (Hsp90) client: Inhibition of Hsp90 leads to ZAP-70 degradation, apoptosis, and impaired signaling in chronic lymphocytic leukemia. Blood 106: 2506-2512, 2005.

19. Bauer S, Yu LK, Demetri GD and Fletcher JA: Heat shock protein 90 inhibition in imatinib-resistant gastrointestinal stromal tumor. Cancer Res 66: 9153-9161, 2006.

20. Stebbins CE, Russo AA, Schneider C, Rosen N, Hartl FU and Pavletich NP: Crystal structure of an Hsp90-geldanamycin complex: Targeting of a protein chaperone by an antitumor agent. Cell 89: 239-250, 1997.

21. Roe SM, Prodromou C, O'Brien R, Ladbury JE, Piper PW and Pearl LH: Structural basis for inhibition of the Hsp90 molecular chaperone by the antitumor antibiotics radicicol and geldanamycin. J Med Chem 42: 260-266, 1999.

22. Prodromou C, Roe SM, O'Brien R, Ladbury JE, Piper PW and Pearl LH: Identification and structural characterization of the ATP/ADP-binding site in the Hsp90 molecular chaperone. Cell 90: 65-75, 1997.

23. Neckers L, Schulte TW and Mimnaugh E: Geldanamycin as a potential anti-cancer agent: Its molecular target and biochemical activity. Invest New Drugs 17: 361-373, 1999.

24. Solit DB, Zheng FF, Drobnjak M, Münster PN, Higgins B, Verbel D, Heller G, Tong W, Cordon-Cardo C, Agus DB, et al: 17-Allylamino-17-demethoxygeldanamycin induces the degradation of androgen receptor and HER-2/neu and inhibits the growth of prostate cancer xenografts. Clin Cancer Res 8: 986-993, 2002.

25. Solit DB, Ivy SP, Kopil C, Sikorski R, Morris MJ, Slovin SF, Kelly WK, DeLaCruz A, Curley T, Heller G, et al: Phase I trial of 17-allylamino-17-demethoxygeldanamycin in patients with advanced cancer. Clin Cancer Res 13: 1775-1782, 2007.

26. Delmotte P and Delmotte-Plaque J: A new antifungal substance of fungal origin. Nature 171: 344, 1953.
27. Soga S, Neckers LM, Schulte TW, Shiotsu Y, Akasaka K, Narumi H, Agatsuma T, Ikuina Y, Murakata C, Tamaoki T and Akinaga S: KF25706, a novel oxime derivative of radicicol, exhibits in vivo antitumor activity via selective depletion of Hsp90 binding signaling molecules. Cancer Res 59: 2931-2938, 1999.

28. Chiosis G, Timaul MN, Lucas B, Munster PN, Zheng FF, Sepp-Lorenzino L and Rosen N: A small molecule designed to bind to the adenine nucleotide pocket of Hsp90 causes Her2 degradation and the growth arrest and differentiation of breast cancer cells. Chem Biol 8: 289-299, 2001.

29. Taldone T and Chiosis G: Purine-scaffold Hsp90 inhibitors. Curr Top Med Chem 9: 1436-1446, 2009.

30. Lundgren K, Zhang H, Brekken J, Huser N, Powell RE, Timple N, Busch DJ, Neely L, Sensintaffar JL, Yang YC, et al: BIIB021, an orally available, fully synthetic small-molecule inhibitor of the heat shock protein Hsp90. Mol Cancer Ther 8: 921-929, 2009.

31. Zhang H, Neely L, Lundgren K, Yang YC, Lough R, Timple N and Burrows F: BIIB021, a synthetic Hsp90 inhibitor, has broad application against tumors with acquired multidrug resistance. Int J Cancer 126: 1226-1234, 2010.

32. Karvela M, Helgason GV and Holyoake TL: Mechanisms and novel approaches in overriding tyrosine kinase inhibitor resistance in chronic myeloid leukemia. Expert Rev Anticancer Ther 12: 381-392, 2012.

33. Jain P, Kantarjian H, Jabbour E, Gonzalez GN, Borthakur G, Pemmaraju N, Daver N, Gachimova E, Ferrajoli A, Kornblau S, et al: Ponatinib as first-line treatment for patients with chronic myeloid leukaemia in chronic phase: A phase 2 study. Lancet Haematol 2: e376-e383, 2015

34. Khajapeer KV and Baskaran R: Hsp90 inhibitors for the treatment of chronic myeloid leukemia. Leuk Res Treatment 2015: $757694,2015$.

35. He W, Ye X, Huang X, Lel W, You L, Wang L, Chen X and Qian W: Hsp90 inhibitor, BIIB021, induces apoptosis and autophagy by regulating mTOR-Ulk1 pathway in imatinib-sensitive and -resistant chronic myeloid leukemia cells. Int J Oncol 48: 1710-1720, 2016.

36. Heidel FH, Bullinger L, Feng Z, Wang Z, Neff TA, Stein L, Kalaitzidis D, Lane SW and Armstrong SA: Genetic and pharmacologic inhibition of $\beta$-catenin targets imatinib-resistant leukemia stem cells in CML. Cell Stem Cell 10: 412-424, 2012.

37. Li H, Wang P, Sun Q, Ding WX, Yin XM, Sobol RW, Stolz DB, Yu J and Zhang L: Following cytochrome c release, autophagy is inhibited during chemotherapy-induced apoptosis by caspase 8 -mediated cleavage of Beclin 1. Cancer Res 71: 3625-3634, 2011

38. Wirawan E, Vande Walle L, Kersse K, Cornelis S, Claerhout S, Vanoverberghe I, Roelandt R, De Rycke R, Verspurten J, Declercq W, et al: Caspase-mediated cleavage of Beclin-1 inactivates Beclin-1-induced autophagy and enhances apoptosis by promoting the release of proapoptotic factors from mitochondria. Cell Death Dis 1: e18, 2010.

39. Glimelius I and Diepstra A: Novel treatment concepts in Hodgkin lymphoma. J Intern Med 281: 247-260, 2017.

40. Georgakis GV, Li Y, Rassidakis GZ, Martinez-Valdez H, Medeiros LJ and Younes A: Inhibition of heat shock protein 90 function by 17-allylamino-17-demethoxy-geldanamycin in Hodgkin's lymphoma cells down-regulates Akt kinase, dephosphorylates extracellular signal-regulated kinase, and induces cell cycle arrest and cell death. Clin Cancer Res 12: 584-590, 2006.

41. Broemer M, Krappmann D and Scheidereit C: Requirement of Hsp90 activity for IkappaB kinase (IKK) biosynthesis and for constitutive and inducible IKK and NF-kappaB activation. Oncogene 23: 5378-5386, 2004

42. Janz M, Stühmer T, Vassilev LT and Bargou RC: Pharmacologic activation of p53-dependent and p53-independent apoptotic pathways in Hodgkin/Reed-Sternberg cells. Leukemia 21: 772-779, 2007.

43. Boll B, Eltaib F, Reiners KS, von Tresckow B, Tawadros S, Simhadri VR, BurrowsFJ,Lundgren K,Hansen HP,Engert A, etal: Heat shock protein 90 inhibitor BIIB021 (CNF2024) depletes NF-kappaB and sensitizes Hodgkin's lymphoma cells for natural killer cell-mediated cytotoxicity. Clin Cancer Res 15: 5108-5116, 2009.

44. Strid J, Roberts SJ, Filler RB, Lewis JM, Kwong BY, Schpero W, Kaplan DH, Hayday AC and Girardi M: Acute upregulation of an NKG2D ligand promotes rapid reorganization of a local immune compartment with pleiotropic effects on carcinogenesis. Nat Immunol 9: 146-154, 2008. 
45. Friese MA, Platten M, Lutz SZ, Naumann U, Aulwurm S, Bischof F, Bühring HJ, Dichgans J, Rammensee HG, Steinle A and Weller M: MICA/NKG2D-mediated immunogene therapy of experimental gliomas. Cancer Res 63: 8996-9006, 2003.

46. Nador RG, Cesarman E, Chadburn A, Dawson DB, Ansari MQ, Sald $\mathbf{J}$ and Knowles DM: Primary effusion lymphoma: A distinct clinicopathologic entity associated with the Kaposi's sarcoma-associated herpes virus. Blood 88: 645-656, 1996.

47. Gopalakrishnan R, Matta $\mathrm{H}$ and Chaudhary PM: A purine scaffold HSP90 inhibitor BIIB021 has selective activity against KSHV-associated primary effusion lymphoma and blocks vFLIP K13-induced NF-kB. Clin Cancer Res 19: 5016-5026, 2013.

48. Suzuki M, Takeda T, Nakagawa H, Iwata S, Watanabe T, Siddiquey MN, Goshima F, Murata T, Kawada J, Ito Y, et al: The heat shock protein 90 inhibitor BIIB021 suppresses the growth of T and natural killer cell lymphomas. Front Microbiol 6: 280, 2015.

49. Ferrando AA, Neuberg DS, Staunton J, Loh ML, Huard C, Raimondi SC, Behm FG,Pui CH, Downing JR, Gilliland DG, et al: Gene expression signatures define novel oncogenic pathways in T cell acute lymphoblastic leukemia. Cancer Cell 1: 75-87, 2002.

50. Li M, Zhang X, Zhou WJ, Chen YH, Liu H, Liu L, Yang CM and Qan WB: Hsp90 inhibitor BIIB021 enhances triptolide-induced apoptosis of human T-cell acute lymphoblastic leukemia cells in vitro mainly by disrupting p53-MDM2 balance. Acta Pharmacol Sin 34: 1545-1553, 2013.

51. Lin S, Li J, Zhou W, Qian W, Wang B and Chen Z: BIIB021, an Hsp90 inhibitor, effectively kills a myelodysplastic syndrome cell line via the activation of caspases and inhibition of PI3K/Akt and NF-kB pathway proteins. Exp Ther Med 7: $1539-1544,2014$

52. Rubin BP, Heinrich MC and Corless CL: Gastrointestinal stromal tumour. Lancet 369: 1731-1741, 2007.

53. Chen LL, Trent JC, Wu EF, Fuller GN, Ramdas L, Zhang W, Raymond AK, Prieto VG, Oyedeji CO, Hunt KK, et al: A missense mutation in KIT kinase domain 1 correlates with imatinib resistance in gastrointestinal stromal tumors. Cancer Res 64: 5913-5919, 2004.

54. Gramza AW, Corless CL and Heinrich MC: Resistance to tyrosine kinase inhibitors in gastrointestinal stromal tumors. Clin Cancer Res 15: 7510-7518, 2009.

55. Solit DB and Rosen N: Hsp90: A novel target for cancer therapy Curr Top Med Chem 6: 1205-1214, 2006.

56. Dickson MA, Okuno SH, Keohan ML, Maki RG, D'Adamo DR, Akhurst TJ, Antonescu CR and Schwartz GK: phase II study of the HSP90-inhibitor BIIB021 in gastrointestinal stromal tumors. Ann Oncol 24: 252-257, 2013.

57. Saif MW, Takimoto C, Mita M, Banerji U, Lamanna N, Castro J, O'Brien S, Stogard C and Von Hoff D: A phase 1, dose-escalation, pharmacokinetic and pharmacodynamic study of BIIB021 administered orally in patients with advanced solid tumors. Clin Cancer Res 20: 445-455, 2014

58. Ballestas ME, Chatis PA and Kaye KM: Efficient persistence of extrachromosomal KSHV DNA mediated by latency-associated nuclear antigen. Science 284: 641-644, 1999.

59. Ballestas ME and Kaye KM: Kaposi's sarcoma-associated herpesvirus latency-associated nuclear antigen 1 mediates episome persistence through cis-acting terminal repeat (TR) sequence and specifically binds TR DNA. J Virol 75: 3250-3258, 2001.

60. Chen W, Sin SH, Wen KW, Damania B and Dittmer DP: Hsp90 inhibitors are efficacious against Kaposi Sarcoma by enhancing the degradation of the essential viral gene LANA, of the viral co-receptor EphA2 as well as other client proteins. PLoS Pathog 8: e1003048, 2012.

61. Yin X, Zhang H, Lundgren K, Wilson L, Burrows $\mathrm{F}$ and Shores CG: BIIB021, a novel Hsp90 inhibitor, sensitizes head and neck squamous cell carcinoma to radiotherapy. Int J Cancer 126: 1216-1225, 2010

62. Wang XT, Bao CH, Jia YB, Wang N, Ma W, Liu F, Wang C, Wang JB, Song QX and Cheng YF: BIIB021, a novel Hsp90 inhibitor, sensitizes esophageal squamous cell carcinoma to radiation. Biochem Biophys Res Commun 452: 945-950, 2014.

63. Kim SH, Kang JG, Kim CS, Ihm SH, Choi MG, Yoo HJ and Lee SJ: Synergistic cytotoxicity of BIIB021 with triptolide through suppression of PI3K/Akt/mTOR and NF-kB signal pathways in thyroid carcinoma cells. Biomed Pharmacother 83 22-32, 2016.
64. Yufu Y, Nishimura J and Nawata H: High constitutive expression of heat shock protein 90 alpha in human acute leukemia cells. Leuk Res 16: 597-605, 1992.

65. Chant ID, Rose PE and Morris AG: Analysis of heat-shock protein expression in myeloid leukaemia cells by flow cytometry. Br J Haematol 90: 163-168, 1995.

66. Mitsiades CS, Mitsiades NS, McMullan CJ, Poulaki V, Kung AL, Davies FE, Morgan G, Akiyama M, Shringarpure R, Munshi NC, et al: Antimyeloma activity of heat shock protein-90 inhibition. Blood 107: 1092-1100, 2006.

67. Valbuena JR, Rassidakis GZ, Lin P, Atwell C, Georgakis GV, Younes A, Jones D and Medeiros LJ: Expression of heat-shock protein-90 in non-Hodgkin's lymphomas. Mod Pathol 18: $1343-1349,2005$

68. Milani M, Laranjeira AB, de Vasconcellos JF, Brandalise SR, Nowill AE and Yunes JA: Plasma Hsp90 level as a marker of early acute lymphoblastic leukemia engraftment and progression in mice. PLoS One 10: e0129298, 2015.

69. Flandrin P, Guyotat D, Duval A, Cornillon J, Tavernier E, Nadal $N$ and Campos L: Significance of heat-shock protein (HSP) 90 expression in acute myeloid leukemia cells. Cell Stress Chaperones 13: 357-364, 2008.

70. Reikvam H, Hatfield KJ, Ersvaer E, Hovland R, Skavland J, Gjertsen BT, Petersen K and Bruserud O: Expression profile of heat shock proteins in acute myeloid leukaemia patients reveals a distinct signature strongly associated with FLT3 mutation status-consequences and potentials for pharmacological intervention. Br J Haematol 156: 468-480, 2012.

71. Tsai HJ, Shih NY, Kuo SH, Cheng AL, Lin HY, Chen TY, Chang KC, Lin SF, Chang JS and Chen LT: AUY922 effectively targets against activated B cell subtype of diffuse large B-cell lymphoma and low-grade lymphoma cells harboring genetic alteration-associated nuclear factor-kB activation. Leuk Lymphoma 56: 2674-2682, 2015.

72. Cerchietti LC, Lopes EC, Yang SN, Hatzi K, Bunting KL, Tsikitas LA, Mallik A, Robles AI, Walling J, Varticovski L, et al: A purine scaffold Hsp90 inhibitor destabilizes BCL-6 and has specific antitumor activity in BCL-6-dependent B cell lymphomas. Nat Med 15: 1369-1376, 2009.

73. Sanda T, Tyner JW, Gutierrez A, Ngo VN, Glover J, Chang BH, Yost A, Ma W, Fleischman AG, Zhou W, et al: TYK2-STAT1-BCL2 pathway dependence in T-cell acute lymphoblastic leukemia. Cancer Discov 3: 564-577, 2013.

74. Taipale M, Krykbaeva I, Koeva M, Kayatekin C, Westover KD, Karras GI and Lindquist S: Quantitative analysis of HSP90-client interactions reveals principles of substrate recognition. Cell 150: 987-1001, 2012

75. Caldas-Lopes E, Cerchietti L, Ahn JH, Clement CC, Robles AI, Rodina A, Moulick K, Taldone T, Gozman A, Guo Y, et al: Hsp90 inhibitor PU-H71, a multimodal inhibitor of malignancy, induces complete responses in triple-negative breast cancer models. Proc Natl Acad Sci USA 106: 8368-8373, 2009.

76. Akahane K, Sanda T, Mansour MR, Radimerski T, DeAngelo DJ, Weinstock DM and Look AT: HSP90 inhibition leads to degradation of the TYK2 kinase and apoptotic cell death in T-cell acute lymphoblastic leukemia. Leukemia 30: 219-228, 2016.

77. Georgakis GV, Li Y and Younes A: The heat shock protein 90 inhibitor 17-AAG induces cell cycle arrest and apoptosis in mantle cell lymphoma cell lines by depleting cyclin D1, Akt, Bid and activating caspase 9. Br J Haematol 135: 68-71, 2006 .

78. Sugimoto K, Sasaki M, Isobe Y, Tsutsui M, Suto H, Ando J, Tamayose K, Ando M and Oshimi K: Hsp90-inhibitor geldanamycin abrogates G2 arrest in p53-negative leukemia cell lines through the depletion of Chk1. Oncogene 27: 3091-3101, 2008.

79. George P, Bali P, Annavarapu S, Scuto A, Fiskus W, Guo F, Sigua C, Sondarva G, Moscinski L, Atadja P and Bhalla K: Combination of the histone deacetylase inhibitor LBH589 and the hsp90 inhibitor 17-AAG is highly active against human CML-BC cells and AML cells with activating mutation of FLT-3. Blood 105: 1768-1776, 2005.

80. Yu C, Kancha RK and Duyster J: Targeting oncoprotein stability overcomes drug resistance caused by FLT3 kinase domain mutations. PLoS One 9: e97116, 2014

81. Al Shaer L, Walsby E, Gilkes A, Tonks A, Walsh V, Mills K, Burnett A and Rowntree C: Heat shock protein 90 inhibition is cytotoxic to primary AML cells expressing mutant FLT3 and results in altered downstream signalling. Br J Haematol 141: 483-493, 2008 
82. Beghini A, Peterlongo P, Ripamonti CB, Larizza L, Cairoli R, Morra $\mathrm{E}$ and Mecucci C: C-kit mutations in core binding factor leukemias. Blood 95: 726-727, 2000

83. Tsujimura A, Kiyoi H, Shiotsu Y, Ishikawa Y, Mori Y, Ishida H, Toki T, Ito E and Naoe T: Selective KIT inhibitor KI-328 and HSP90 inhibitor show different potency against the type of KIT mutations recurrently identified in acute myeloid leukemia. Int $\mathrm{J}$ Hematol 92: 624-633, 2010.

84. Barnes DJ, De S, van Hensbergen P, Moravcsik E and Melo JV: Different target range and cytotoxic specificity of adaphostin and 17-allylamino-17-demethoxygeldanamycin in imatinib-resistant and sensitive cell lines. Leukemia 21: 421-426, 2007.

85. Jin L, Xiao CL, Lu CH, Xia M, Xing GW, Xiong S, Liu QY, Liu H, Li YC, Ge F, et al: Transcriptomic and proteomic approach to studying SNX-2112-induced K562 cells apoptosis and anti-leukemia activity in K562-NOD/SCID mice. FEBS Lett 583: 1859-1866, 2009.

86. Peng C, Brain J, Hu Y, Goodrich A, Kong L, Grayzel D, Pak R, Read M and Li S: Inhibition of heat shock protein 90 prolongs survival of mice with BCR-ABL-T315I-induced leukemia and suppresses leukemic stem cells. Blood 110: 678-685, 2007.

87. Radujkovic A, Schad M, Topaly J, Veldwijk MR, Laufs S, Schultheis BS, Jauch A, Melo JV, Fruehauf S and Zeller WJ Synergistic activity of imatinib and 17-AAG in imatinib-resistant CML cells overexpressing BCR-ABL-Inhibition of P-glycoprotein function by 17-AAG. Leukemia 19: 1198-1206, 2005

88. Tauchi T, Okabe S, Ashihara E, Kimura S, Maekawa T and Ohyashiki K: Combined effects of novel heat shock protein 90 inhibitor NVP-AUY922 and nilotinib in a random mutagenesis screen. Oncogene 30: 2789-2797, 2011

89. Marubayashi S, Koppikar P, Taldone T, Abdel-Wahab O, West N, Bhagwat N, Caldas-Lopes E, Ross KN, Gonen M, Gozman A, et al: HSP90 is a therapeutic target in JAK2-dependent myeloproliferative neoplasms in mice and humans. J Clin Invest 120: 3578-3593, 2010.

90. Hertlein E, Wagner AJ, Jones J, Lin TS, Maddocks KJ, Towns WH III, Goettl VM, Zhang X, Jarjoura D, Raymond CA, et al: 17-DMAG targets the nuclear factor-kappaB family of proteins to induce apoptosis in chronic lymphocytic leukemia: Clinical implications of HSP90 inhibition. Blood 116: 45-53, 2010.

91. Walsby E, Pearce L, Burnett AK, Fegan C and Pepper C: The Hsp90 inhibitor NVP-AUY922-AG inhibits NF-kB signaling, overcomes microenvironmental cytoprotection and is highly synergistic with fludarabine in primary CLL cells. Oncotarget 3 : $525-534,2012$.

92. Trentin L, Frasson M, Donella-Deana A, Frezzato F, Pagano MA, Tibaldi E, Gattazzo C, Zambello R, Semenzato G and Brunati AM: Geldanamycin-induced Lyn dissociation from aberrant Hsp90-stabilized cytosolic complex is an early event in apoptotic mechanisms in B-chronic lymphocytic leukemia. Blood 112: 4665-4674, 2008.

93. Chen TL, Gupta N, Lehman A, Ruppert AS, Yu L, Oakes CC Claus R, Plass C, Maddocks KJ, Andritsos L, et al: Hsp90 inhibition increases SOCS3 transcript and regulates migration and cell death in chronic lymphocytic leukemia. Oncotarget 7: 28684-28696, 2016.

94. Gao L and Harhaj EW: HSP90 protects the human T-cell leukemia virus type 1 (HTLV-1) tax oncoprotein from proteasomal degradation to support NF-kB activation and HTLV-1 replication. J Virol 87: 13640-13654, 2013.

95. Taniguchi H, Hasegawa H, Sasaki D, Ando K, Sawayama Y, Imanishi D, Taguchi J, Imaizumi Y, Hata T, Tsukasaki K, et al: Heat shock protein 90 inhibitor NVP-AUY922 exerts potent activity against adult T-cell leukemia-lymphoma cells. Cancer Sci 105: 1601-1608, 2014.

96. Kurashina R, Ohyashiki JH, Kobayashi C, Hamamura R, Zhang Y,Hirano T and Ohyashiki K: Anti-proliferative activity of heat shock protein (Hsp) 90 inhibitors via beta-catenin/TCF7L2 pathway in adult T cell leukemia cells. Cancer Lett 284: 62-70, 2009.

97. Ikebe E, Kawaguchi A, Tezuka K, Taguchi S, Hirose S, Matsumoto T, Mitsui T, Senba K, Nishizono A, Hori M, et al: Oral administration of an HSP90 inhibitor, 17-DMAG, intervenes tumor-cell infiltration into multiple organs and improves survival period for ATL model mice. Blood Cancer J 3: e132, 2013.
98. Okawa Y, Hideshima T, Steed P, Vallet S, Hall S, Huang K, Rice J, Barabasz A, Foley B, Ikeda H, et al: SNX-2112, a selective Hsp90 inhibitor, potently inhibits tumor cell growth, angiogenesis, and osteoclastogenesis in multiple myeloma and other hematologic tumors by abrogating signaling via Akt and ERK. Blood 113: 846-855, 2009.

99. Nakashima T, Ishii T, Tagaya H, Seike T, Nakagawa H, Kanda Y, Akinaga S, Soga S and Shiotsu Y: New molecular and biological mechanism of antitumor activities of KW-2478, a novel nonansamycin heat shock protein 90 inhibitor, in multiple myeloma cells. Clin Cancer Res 16: 2792-2802, 2010.

100. McCaig AM, Cosimo E, Leach MT and Michie AM: Dasatinib inhibits B cell receptor signalling in chronic lymphocytic leukaemia but novel combination approaches are required to overcome additional pro-survival microenvironmental signals. Br J Haematol 153: 199-211, 2011.

101. Lin K, Rockliffe N, Johnson GG, Sherrington PD and Pettitt AR: Hsp90 inhibition has opposing effects on wild-type and mutant p53 and induces p21 expression and cytotoxicity irrespective of p53/ATM status in chronic lymphocytic leukaemia cells. Oncogene 27: 2445-2455, 2008.

102. Best OG, Singh N, Forsyth C and Mulligan SP: The novel Hsp-90 inhibitor SNX7081 is significantly more potent than 17-AAG against primary CLL cells and a range of haematological cell lines, irrespective of lesions in the TP53 pathway. Br J Haematol 151: 185-188, 2010.

103. Best OG, Che Y, Singh N, Forsyth C, Christopherson RI and Mulligan SP: The Hsp90 inhibitor SNX-7081 synergizes with and restores sensitivity to fludarabine in chronic lymphocytic leukemia cells with lesions in the TP53 pathway: A potential treatment strategy for fludarabine refractory disease. Leuk Lymphoma 53: 1367-1375, 2012.

104. Weigert O, Lane AA, Bird L, Kopp N, Chapuy B, van Bodegom D, Toms AV, Marubayashi S, Christie AL, McKeown M, et al: Genetic resistance to JAK2 enzymatic inhibitors is overcome by HSP90 inhibition. J Exp Med 209: 259-273, 2012.

105. Ghia P, Chiorazzi N and Stamatopoulos K: Microenvironmental influences in chronic lymphocytic leukaemia: The role of antigen stimulation. J Intern Med 264: 549-562, 2008.

106. Newman B, Liu Y, Lee HF, Sun D and Wang Y: HSP90 inhibitor 17-AAG selectively eradicates lymphoma stem cells. Cancer Res 72: 4551-4561, 2012.

107. Kim HB, Lee SH, Um JH, Kim MJ, Hyun SK, Gong EJ, Oh WK, Kang CD and Kim SH: Sensitization of chemo-resistant human chronic myeloid leukemia stem-like cells to Hsp90 inhibitor by SIRT1 inhibition. Int J Biol Sci 11: 923-934, 2015.

108. Born EJ, Hartman SV and Holstein SA: Targeting HSP90 and monoclonal protein trafficking modulates the unfolded protein response, chaperone regulation and apoptosis in myeloma cells. Blood Cancer J 3: e167, 2013.

109. Huston A, Leleu X, Jia X, Moreau AS, Ngo HT, Runnels J, Anderson J, Alsayed Y, Roccaro A, Vallet S, et al: Targeting Akt and heat shock protein 90 produces synergistic multiple myeloma cell cytotoxicity in the bone marrow microenvironment. Clin Cancer Res 14: 865-874, 2008.

110. Ishii T, Seike T, Nakashima T, Juliger S, Maharaj L, Soga S, Akinaga S, Cavenagh J, Joel S and Shiotsu Y: Anti-tumor activity against multiple myeloma by combination of KW-2478, an Hsp90 inhibitor, with bortezomib. Blood Cancer J 2: e68, 2012.

111. Chatterjee M, Andrulis M, Stühmer T, Müller E, Hofmann C, Steinbrunn T, Heimberger T, Schraud H, Kressmann S, Einsele $\mathrm{H}$ and Bargou RC: The PI3K/Akt signaling pathway regulates the expression of Hsp70, which critically contributes to Hsp90-chaperone function and tumor cell survival in multiple myeloma. Haematologica 98: 1132-1141, 2013.

112. Kaiser M, Lamottke B, Mieth M, Jensen MR, Quadt C, Garcia-Echeverria C, Atadja P, Heider U, von Metzler I, Türkmen S and Sezer O: Synergistic action of the novel HSP90 inhibitor NVP-AUY922 with histone deacetylase inhibitors, melphalan, or doxorubicin in multiple myeloma. Eur J Haematol 84: 337-344, 2010.

113. Francis LK, Alsayed Y, Leleu X, Jia X, Singha UK, Anderson J, Timm M, Ngo H, Lu G, Huston A, et al: Combination mammalian target of rapamycin inhibitor rapamycin and HSP90 inhibitor 17-allylamino-17-demethoxygeldanamycin has synergistic activity in multiple myeloma. Clin Cancer Res 12: 6826-6835, 2006. 
114. Goldstein RL, Yang SN, Taldone T, Chang B, Gerecitano J, Elenitoba-Johnson K, Shaknovich R, Tam W, Leonard JP, Chiosis G, et al: Pharmacoproteomics identifies combinatorial therapy targets for diffuse large B cell lymphoma. J Clin Invest 125: 4559-4571, 2015 .

115. Roué G, Pérez-Galan P, Mozos A, López-Guerra M, Xargay-Torrent S, Rosich L, Saborit-Villarroya I, Normant E, Campo E and Colomer D: The Hsp90 inhibitor IPI-504 overcomes bortezomib resistance in mantle cell lymphoma in vitro and in vivo by down-regulation of the prosurvival ER chaperone BiP/Grp78. Blood 117: 1270-1279, 2011.

116. Walsby EJ, Lazenby M, Pepper CJ, Knapper S and Burnett AK: The HSP90 inhibitor NVP-AUY922-AG inhibits the PI3K and IKK signalling pathways and synergizes with cytarabine in acute myeloid leukaemia cells. Br J Haematol 161: 57-67, 2013.

117. Lazenby M, Hills R, Burnett AK and Zabkiewicz J: The HSP90 inhibitor ganetespib: A potential effective agent for Acute Myeloid Leukemia in combination with cytarabine. Leuk Res 39: 617-624, 2015.

118. Mesa RA, Loegering D, Powell HL, Flatten K, Arlander SJ, Dai NT, Heldebrant MP, Vroman BT, Smith BD, Karp JE, et al: Heat shock protein 90 inhibition sensitizes acute myelogenous leukemia cells to cytarabine. Blood 106: 318-327, 2005.

119. Lancet JE, Gojo I, Burton M, Quinn M, Tighe SM, Kersey K, Zhong Z, Albitar MX, Bhalla K, Hannah AL, et al: Phase I study of the heat shock protein 90 inhibitor alvespimycin (KOS-1022, 17-DMAG) administered intravenously twice weekly to patients with acute myeloid leukemia. Leukemia 24: 699-705, 2010.
120. Kaufmann SH, Karp JE, Litzow MR, Mesa RA, Hogan W, Steensma DP, Flatten KS, Loegering DA, Schneider PA, Peterson KL, et al: Phase I and pharmacological study of cytarabine and tanespimycin in relapsed and refractory acute leukemia. Haematologica 96: 1619-1626, 2011.

121. Yong K, Cavet J, Johnson P, Morgan G, Williams C, Nakashima D, Akinaga S, Oakervee $H$ and Cavenagh J: phase I study of KW-2478, a novel Hsp90 inhibitor, in patients with B-cell malignancies. Br J Cancer 114: 7-13, 2016.

122. Richardson PG, Chanan-Khan AA, Lonial S, Krishnan AY Carroll MP, Alsina M, Albitar M, Berman D, Messina M and Anderson KC: Tanespimycin and bortezomib combination treatment in patients with relapsed or relapsed and refractory multiple myeloma: Results of a phase 1/2 study. Br J Haematol 153: 729-740, 2011

123. Oki Y, Copeland A, Romaguera J, Fayad L, Fanale M, Faria Sde C, Medeiros LJ, Ivy P and Younes A: Clinical experience with the heat shock protein-90 inhibitor, tanespimycin, in patients with relapsed lymphoma. Leuk Lymphoma 53: 990-992, 2012.

124. Oki Y, Younes A, Knickerbocker J, Samaniego F, Nastoupil L, Hagemeister F, Romaguera J, Fowler N, Kwak L and Westin J: Experience with HSP90 inhibitor AUY922 in patients with relapsed or refractory non-Hodgkin lymphoma. Haematologica 100: e272-e274, 2015.

125. Maddocks K, Hertlein E, Chen TL, Wagner AJ, Ling Y, Flynn J, Phelps M, Johnson AJ, Byrd JC and Jones JA: A phase I trial of the intravenous Hsp90 inhibitor alvespimycin (17-DMAG) in patients with relapsed chronic lymphocytic leukemia/small lymphocytic lymphoma. Leuk Lymphoma 57: 2212-2215, 2016. 